\title{
ANTHROPOS:
}

Jurnal Antropologi Sosial dan Budaya

Available online http://jurnal.unimed.ac.id/2012/index.php/anthropos

\section{Peran Kepemimpinan Kepala Madrasah dalam Meningkatkan Mutu Pendidikan di MTs. Swasta Miftahul Falah Sunggal Kabupaten Deli Serdang}

\author{
Mustapid1), Ahmad Ibrahim Hasibuan²) \& Candra Wijaya ${ }^{3) *}$ \\ 1) Kementerian Agama Sumatera Utara, Indonesia \\ 2) Sekolah Tinggi Ilmu Tarniyah Al Hikmah Tebing Tinggi, Indonesia \\ 3) Manajemen Pendidikan Islam, Fakultas Ilmu Tarbiyah dan Keguruan, \\ Universitas Islam Negeri Sumatera Utara, Indonesia
}

Diterima: Januari 2019; Disetujui: Januari 2019; Diterbitkan: Januari 2019

\begin{abstract}
Abstrak
Mutu pendidikan hendaknya mampu menghasilkan lulusan yang terampil, mampu sesuai dengan tingkat pendidikannya, jujur dan yang terpenting lagi adalah moralnya baik. Peningkatan mutu pendidikan yang lebih berkualitas antara lain melalui pengembangan dan perbaikan kurikulum dan sistem evaluasi, perbaikan sarana pendidikan, pengembangan dan pengadaan materi ajar, serta pelatihan bagi guru dan tenaga kependidikan lainnya. Tujuan dari penelitian ini adalah untuk mengetahui yang dijalankan kepala madrasah di MTs. Swasta Miftahul Falah Diski. Metode yang digunakan dalam penelitian ini adalah metode kualitatif dengan pendekatan deskriptif analisis yaitu metode penelitian yang menghasilkan data deskriptif berupa kata-kata tertulis atau lisan dari orang-orang sebagai objek penelitian dan perilaku yang dapat diamati sehingga merupakan rinci dari suatu fenomena yang diteliti. Berdasarkan hasil penelitian ditemukan bahwa kepemimpinan yang dijalankan kepala madrasah di MTs. Swasta Miftahul Falah Diski tergolong kepada tipe kepemimpinan demokratis dimana kepala madrasah selalu mengadakan musyawarah kepada seluruh dewan guru, staf dan tata usaha dalam menetapkan setiap keputusan yang akan diambil. Mutu pendidikan di MTs. Swasta Miftahul Falah Diski sudah memenuhi 8 Standar Nasioanal Pendidikan, dan dibuktikan dengan terakreditasinya MTs Swasta Miftahul Falah Diski dengan perolehan akreditasi B.
\end{abstract}

Kata Kunci: Peran, Kepemimpinan, Kepala Madrasah, Mutu Pendidikan.

\begin{abstract}
The quality of education should be able to produce skilled graduates, capable of being in accordance with their level of education, honest and most importantly, good morals. Improving the quality of education that is more qualified, among others, through the development and improvement of curriculum and evaluation systems, improvement of educational facilities, development and procurement of teaching materials, and training for teachers and other education personnel. The purpose of this study is to find out what the madrasa principals do at MTs. Private Miftahul Falah Diski. The method used in this study is a qualitative method with a descriptive analysis approach that is a research method that produces descriptive data in the form of written or oral words from people as research objects and observable behaviors so that they are detailed from a phenomenon under study. Based on the results of the study it was found that the leadership carried out by the head of the madrasa in MTs. Private Miftahul Falah Diski is classified into the type of democratic leadership in which the head of the madrasa always holds deliberations to the entire board of teachers, staff and administration in determining each decision to be made. Quality of education in MTs. Private Miftahul Falah I have fulfilled 8 National Education Standards, and it is evidenced by the accreditation of MTs Private Miftahul Falah with the accreditation of B. Keywords: Role, Leadership, Head of Madrasah, Quality of Education.
\end{abstract}

How to Cite: Mustapid, Hasibuan A.I. \& Wijaya, C. (2019). Peran Kepemimpinan Kepala Madrasah dalam Meningkatkan Mutu Pendidikan di MTs. Swasta Miftahul Falah Sunggal Kabupaten Deli Serdang. Anthropos: Jurnal Antropologi Sosial dan Budaya, 4 (2): 201-210.

\begin{tabular}{lc}
\hline *Corresponding author: & ISSN 2460-4585 (Print) \\
E-mail: natamanadenggan@gmail.com & ISSN 2460-4593 (Online)
\end{tabular}




\section{PENDAHULUAN}

Pemimpin dalam madrasah merupakan seorang tenaga fungsional guru yang diberi tugas untuk memimpin suatu sekolah di mana diselenggarakan proses belajar mengajar atau tempat dimana terjadi interaksi antara guru yang memberi pelajaran dan murid yang menerima pelajaran. Dengan ini Kepala madrasah bisa dikatakan sebagai pemimpin di satuan pendidikan yang tugasnya menjalankan menejemen satuan pendidikan yang dipimpin. Pada tingkat operasional, Kepala madrasah adalah orang yang berada di garis terdepan yang mengkoordinasikan upaya meningkatkan pembelajaran yang bermutu. Kepala madrasah diangkat untuk menduduki jabatan bertanggung jawab mengkoordinasikan upaya bersama mencapai tujuan pendidikan pada level sekolah yang dipimpin.

Mulyasa (2007) memberi penjelasan tentang pengertian bahwa kepala madrasah merupakan salah satu komponen pendidikan yang paling berperan dalam meningkatkan kualitas pendidikan. Kepala madrasah adalah penanggung jawab atas penyelenggaraan pendidikan, administrasi sekolah, pembinaan tenaga pendidikan lainnya, pendayagunaan serta pemeliharaan sarana dan prasarana juga sebagai supervisor pada sekolah yang dipimpinnya. Mulai dari tindak lanjut hasil penilaian terhadap perencanaan pembelajaran guru, hingga tindak lanjut atas performa guru dalam kegiatan pembelajaran di dalam kelas. Sebagai tindak lanjut dari hasil evaluasi yang telah di dapat oleh kepala sekolah, ada diskusi kecil yang dilaksanakan antara kepala sekolah dan guru kelas yang telah dievaluasi. (Siregar, A.B., Kusmanto, \& Isnaini, 2016). Tentu saja Kepala madrasah bukan satu-satunya yang bertanggung jawab penuh terhadap suatu sekolah, karena masih banyak faktor lain yang perlu diperhitungkan seperti: guru, peserta didik, dan lingkungan yang mempengaruhi proses pembelajaran. Namun Kepala madrasah memiliki peran yang sangat mempengaruhi jalannya sistem yang ada dalam sekolah.

Pendidikan merupakan sebuah institusi yang dapat dikatakan bersifat kompleks dan unik. Bersifat kompleks, karena pendidikan merupakan sebuah organisasi yang didalamnya terdapat keterkaitan berbagai dimensi untuk menuju pencapaian komitmen. Sedangkan keunikan institusi pendidikan didasarkan pada karakteristik tertentu yang tidak dimiliki organisasi lain. Adapun karakteristik tersebut adalah adanya proses belajar mengajar sebagai pemberdayaan umat manusia. Kompleksitas dan keunikan yang dimiliki oleh pendidikan menurut Wahjosumidjo yaitu adanya peran kepala madrasah yang sangat fundamental dalam mewujudkan pencapaian tujuan pendidikan (Wahjosumidjo, 2007). Kepala madrasah mempunyai peran yang sangat penting, dengan adanya kepala madrasah maka suatu lembaga pendidikan dapat terorganisir dengan baik. Hal ini telah tercantum dalam Departemen Pendidikan Nasional Tahun 2006 tentang Peran Kepala Madrasah, bahwa seorang kepala madrasah mempunyai beberapa peran diantaranya sebagai manajer, leader, educator, administrator, inovator, motivator dan supervisor. Maka kepala madrasah berhak dalam menentukan suatu keputusan atau kebijakan dalam pengelolaan suatu proses pendidikan.

Kepala Madrasah adalah unsur pelaksana administrasi dengan tugas dan tanggung jawab menjalankan kegiatan administrasi sehari-hari. Dengan tidak mengecilkan arti keterlibatan komponen yang lain, pegawai merupakan komponen yang paling penting dalam tercapainya tujuan organisasi (A'yuni, Q., (2016). Kepala madrasah dituntut untuk untuk memiliki ide inovasi-inovasi demi mengembangkan lembaga di madrasah yang dipimpinnya. Peran inovator kepala madrasah antara lain melaksanakan pembaruanpembaruan dalam pembelajaran. Berdasarkan Peraturan Menteri Pendidikan Nasional Nomor 13 Tahun 2007 tentang Standar Kepala Madrasah dalam usaha memajukan pendidikan perlu adanya peranan kepala madrasah dalam hal sebagai pendidik, manajer, administrator, supervisor, pemimpin, pencipta iklim kerja dan wirausahawan serta mengatur bahwa kepala madrasah harus memiliki kompetensi dalam menjalankan tugas pokok dan fungsinya. Fungsi utama kepala madrasah sebagai pemimpin pendidikan adalah menciptakan adanya proses belajar mengajar, sehingga guru-guru dapat mengajar dengan caranya masing-masing dan peserta didik dapat belajar dan menerima pelajaran dengan baik. Dalam melaksanakan fungsi tersebut maka seorang kepala madrasah mempunyai tanggung jawab ganda yaitu melaksanakan tugasnya dalam mengelola administrasi sekolah sehingga 
terciptanya situasi belajar dan mengajar yang baik, dan melaksanakan supervisi atau pengawasan sehingga para guru dapat menjalankan tugas-tugas pengajaran dengan baik. Upaya peningkatan mutu pendidikan ada hal yang perlu diperhatikan, antara lain kunci utama dalam peningkatan mutu pendidikan adalah komitmen terhadap perubahan. Jika semua guru dan staff sekolah telah memiliki komitmen pada perubahan yang lebih baik, maka pemimpin akan lebih mudah dalam mengelola dan mendorong mereka untuk menemukan cara baru untuk memperbaiki efisiensi, produktivitas, dan kualitas layanan pendidikan.

Kepemimpinan meliputi proses mempengaruhi dalam menentukan tujuan organisasi, memotivasi perilaku pengikut untuk mencapai tujuan, mempengaruhi untuk memperbaiki kelompok dan budayanya. Menurut Sudarwan Danim (2004) kepemimpinan adalah setiap perbuatan yang dilakukan oleh individu atau kelompok untuk mengkoordinasi dan memberi arah kepada individu atau kelompok yang tergabung di dalam wadah tertentu untuk mencapai tujuan yang telah ditetapkan sebelumnya. Tugas tambahan Kepala madrasah untuk mengontrol dan membimbing guru di satuan pendidikan dapat dilakukan dengan gaya kepemimpinan yang tepat. Gaya kepemimpinan Kepala madrasah sangat berpengaruh pada arah dan tujuan sekolah yang direncanakan sebelumnya, termasuk di dalamnya adalah bagaimana mengoptimalkan guru agar dapat bekerja dengan baik dalam satuan pendidikan tersebut. Untuk itu kepala madrasah harus dapat memberikan motivasi kepada guru.

Pendidikan Islam dan segala problematikanya merupakan kata kunci yang paling sering mendapatkan sorotan dan lahan kajian akademis yang dilakukan oleh berbagai para pakar, peminat dan pelaku pendidikan itu sendiri. Karena pendidikan itu sendiri merupakan sebuah proses tahapan integrative dari tahapan lainnnya dalam sisi lain perubahan kehidupan yang sedang dijalani oleh manusia. Tujuan semua dari perjalanan kehidupan manusia adalah sejauhmana kehidupan yang dijalaninya dapat memberi makna dan warna tersendiri serta dapat menunjukan nilai fitrahnya sebagai manusia, karena itu pendidikan merupakan hal pokok yang mesti manusia dapatkan dan lakukan sebagai arah dan pegangan bagi perjalanan hidup itu sendiri (Syam, 2005). Dunia kehidupan nyata saat ini tidak akan pernah berhenti untuk selalu membicarakan tentang pendidikan dalam berbagai sudut pandang dan permasalahan yang melingkupinya.

Untuk itu pendidikan Islam saat ini sedang dalam tahap menentukan nasib dan masa depan nya sendiri, hal ini di sadari minimnya perhatian pemerintah baik dari segi anggaran maaupun peningkatan lainnya bila dibandingkan dengan institusi yang bernanung di kementrian pendidikan nasioanl yakni sekolah. Realitas permasalah ini bisa dilihat dari beberapa aspek yang terkait dengan sekelumit permasalah pendidikan islam itu sendiri, antara lain adanya dikotomi pendidikan (madrasah vs sekolah), pengembangan dan pemberlakuan kurikulum, pengembangan sumber daya manusia tenaga pendidik dan sebagainya. Prinsip pendidikan yang sesungguhnya harus diberlakukan adalah kemandirian, demokratis, dan berkeadilan.

Permasalahan pendidikan dewasa ini terus muncul seiring upaya untuk penyempurnaan sistem pendidikan nasional. Permasalahan itu setidaknya dilatarbelakangi tempat berdirinya madrasah, antara madrasah yang berada dipedesaan atau diperkotaan. Madrasah yang berada di daerah pedesaan dan diperkotaan pasti akan berbeda baik dari sarana prasarana, sumber daya manusia, ataupun manajemen yang ada disuatu madrasah. Suatu madrasah di daerah terpencil dan diperbatasan masyarakat di daerah ini tertinggal dalam pembangunan baik itu ekonomi, infrastuktur maupun pendidikan. Yang paling utama adalah faktor yang cukup berpengaruh adalah faktor kepemimpinan kepala madrasah. Kepemimpinan kepala madrasah merupakan kemampuan untuk menggerakan faktor-faktor yang mempengaruhi tujuan pendidikan di madrasah. Kepemimpinan kepala madrasah dapat menentukan keberhasilan maupun kualitas pendidikan disebuah sekolah.

Mutu pendidikan hendaknya mampu menghasilkan lulusan yang terampil, mampu sesuai dengan tingkat pendidikannya, jujur dan yang terpenting lagi adalah moralnya baik. Peningkatan mutu pendidikan yang lebih berkualitas antara lain melalui pengembangan dan perbaikan kurikulum dan sistem evaluasi, perbaikan sarana pendidikan, pengembangan dan pengadaan materi ajar, serta pelatihan bagi guru dan tenaga kependidikan 
lainnya. Pencapaian dan peningkatan mutu pendidikan menjadi sebuah harapan, keinginan, tuntutan dan pandangan yang tidak semua orang bisa mengembannya. Dalam hal ini diperlukan seorang kepala madrasah yang profesional. Kepala madrasah yang menerima murid sebanyakbanyaknya, memiliki fasilitas sehebat-hebatnya, menghasilkan lulusan dengan kualitas setinggitingginya, semua itu tertumpu pada seorang kepala madrasah. Maka dari itu kepala madrasah sebagai pemimpin harus jeli dalam membaca peluang dan ancaman yang akan datang, apabila kepala madrasah tidak memperhatikan penentuan keberhasilan maupun kualitas pendidikan disebuah madrasah maka madrasah tersebut akan sulit untuk mencapai mutu pendidikan yang berkualitas.

\section{METODE PENELITIAN}

Metode yang digunakan dalam penelitian ini adalah metode kualitatif dengan pendekatan deskriptif analisis yaitu metode penelitian yang menghasilkan data deskriptif berupa kata-kata tertulis atau lisan dari orang-orang sebagai objek penelitian dan perilaku yang dapat diamati sehingga merupakan rinci dari suatu fenomena yang diteliti (Sugiyono, 2006: 137). Metode kualitatif deskriptif ditujukan untuk mendeskripsikan atau menggambarkan fenomenafenomena yang ada, baik fenomena yang bersifat alamiah ataupun rekayasa manusia (Syaodih, 2012: 72). Penelitian ini dilakukan di MTs. Swasta Miftahul Falah jalan Paya Bakung No.34 Desa Sumber Melati diski kecamatan Sunggal kabupaten Deli Serdang. Sedangkan subjek penelitian yang di maksud dalam penelitian ini yaitu orang-orang yang menjadi sumber dalam penelitian dan dapat memberikan informasi terkait dengan penelitian yang akan di laksanakan. Di dalam penelitian ini subjek yang diambil adalah kepala madrasah, wakil kepala madrasah bidang kurikulum, pegawai administrasi, guru, dan siswa MTs. Swasta Miftahul Falah Diski. Peneliti memilih subjek secara berantai yaitu setelah subjek awal di wawancarai, maka akan berlanjut kepada subjek berikutnya secara terus-menerus sampai data dapat terpenuhi sesuai dengan kebutuhan.

Pengumpulan data dalam kualitatif dilakukan langsung oleh peneliti melalui observasi, wawancara dan pengkajian dokumentasi (Sarwono, 2006: 223). Setelah data informasi yang diperlukan terkumpul selanjutnya dianalisis dalam rangka menemukan makna temuan. Analisis data adalah proses mengorganisasikan dan mengurut data kedalam pola, kategori dan satuan uraian dasar sehingga dapat ditemukan tema dan dapat dirumuskan hipotesis kerja seperti yang disarankan oleh data. analisis data merupakan proses dan mencari, mengatur secara sistematis transkip wawancara, catatan lapangan dan bahanbahan lain yang telah dikumpulkan untuk menambah pemahaman sendiri memungkinkan temuan tersebut dilaporkan kepada pihak lain. Teknik pengelolaan dan analisis data dalam penelitian ini melalui proses klasifikasi atau Deskripsi, pada tahap ini peneliti mendeskripsikan apa yang dilihat, didengar, dirasakan dan ditanyakan. Peneliti biasanya baru mengenal sepintas informasi yang diperolehnya. Selanjutnya reduksi, peneliti mereduksi segala informasi yang telah diperoleh pada tahap pertama untuk memfokuskan pada masalah tertentu. Memilih data mana yang menarik, penting dan berguna, serta baru. Kemudian data tersebut dikelompokan dikategori yang ditetapkan dalam fokus penelitian. Pada tahap selanjutnya Selection atau Interpretasi, pada tahap ini peneliti menguraikan fokus yang telah ditetapkan menjadi lebih rinci.

\section{HASIL DAN PEMBAHASAN \\ Profil MTs Swasta Miftahul Falah Diski}

MTs. Swasta Miftahul Falah jalan Paya Bakung No.34 Desa Sumber Melati diski kecamatan Sunggal kabupaten Deli Serdang. MTs ini telah diakreditasi dan memproleh akreditasi B. Visi MTs Miftahul Falah Diski adalah adanya kebersamaan menghasilkan murid yang berilmu, beriman, bertaqwa dan berprilaku islami. Untuk merealisasikan visi ini dengan melaksanakan misimisi yang telah ditetapkan adalah sebagai berikut: 1) Membina kebersamaan antara guru, orang tua, masyarakat, dan pemerintah untuk memajukan pendidikan di madrasah; 2) Melaksanakan proses pendidikan yang dinamis, kreatif dan inovatif berdasarkan syariat islam dan perudang-undangan yang berlaku; 3) Menanamkan budi pekerti, sopan santun, kemandirian dan kedisiplinan warga madrasah; 4) Menciptakan keteladanan dalam berprilaku islami di kalangan warga madrasah; 5) Melaksanakan pelayanan administrasi pendidikan yang cepat, tepat, dan transparan. 
Berdasarkan data yang diproleh dari pihak sekolah bahwa MTs Swasta Miftahul Falah terakreditasi $\mathrm{B}$, ini memberikan gambaran bahwa kepemimpinan madrasah memiliki keseriusan dalam memimpin madrasah untuk mendapatkan mutu pendidikan yang baik. Satu hal yang unik budaya yang diterapkan di MTs Swasta Miftahul Falah Diski yaitu budaya senyum, salam, sapa. Sekilah hal ini merupakan yang biasa, tetapi jika dilihat pada praktek dilapangan bahwa dengan budaya ini tercipta iklim warga madrasah yang memiliki hubungan kekeluargaan. Karena antara guru dan murid atau sesama warga disekolah saling senyum, sapa dan salam sehingga warga madrasah saling transparan dan percaya. Dengan munculnya hal tersebut maka warga madrasah dengan dorongan dari dalam dirinya untuk melaksanakan peraturan madrasah.

\section{Peran Kepala Madrasah dalam Meningkatkan Mutu MTs Swasta Miftahul Falah Diski}

Untuk meningkatkan mutu madrasah sudah tentu merupakan peran semua warga madrasah dalam keseriusannya dalam meningkatkan mutu. Di balik itu semua, kepala madrasah merupakan faktor utama yang memiliki peran dalam meningkatkan mutu madrasah. Kepala madrasah fungsi utamanya adalah sebagai manager, dengan demikian kepala madrasah memfasilitasi dan memberikan kesempatan yang luas kepada guru untuk dapat melaksanakan kegiatan kegiatan pengembangan profesi melalui berbagai kegiatan pendidikan dan pelatihan, baik yang dilaksanakan di sekolah maupun di luar sekolah. Dalam hal ini, berdasarkan pengamatan peneliti kepala madrasah MTs Swasta Miftahul Falah Diski telah melakukan hal tersebut. Dalam meningkatkan kualitas pendidikan, kepala madrasah MTs Swasta Miftahul Falah Diski menempatkan guru pada jabatan profesional dengan mengadakan pembinaanpembinaan terhadap guru melalui rapat-rapat evaluasi kinerja guru. Ada beberapa hal yang dilakukan oleh kepala madrasah MTs Swasta Miftahul Falah Diski dalam memberikan pembinaan tersebut antara lain sebagai berikut: 1) Pembinaan Tanggung Jawab Guru Madrasah; 2) Pembinaan Kedisiplinan Guru; 3) Program pelaksanaan kegiatan pembelajaran; dan 4) Pemberian penghargaan bagi guru berprestasi dan sanksi bagi guru yang indispliner.
Pada pembinaan tanggung jawab guru, kepala madrasah telah membuat perencanaan penyusunan program maka memungkinkan kegiatan yang akan dilaksanakan berjalan dengan baik, sehingga dapat mencapai hasil dengan baik pula. Penyusunan program merupakan bagian dari proses manajemen yang memiliki arti penting. Program kepala madrasah yang disusun meliputi program pembinaan tanggung jawab guru dalam melaksanakan tugasnya, yaitu terkait dengan persiapan program pembelajaran, pelaksanaan proses pembelajaran dan evaluasi hasil pembelajaran.

Upaya peningkatan kinerja guru yang dilakukan kepala madrasah adalah salah satunya juga dengan menerapkan kedisiplinan guru melalui: (1) pembinaan, (2) pengawasan dan (3) tindakan dalam disiplin. Hal ini dapat di gambarkan bahwa kepala MTs Swasta Miftahul Falah Diski dalam membina disiplin guru melalui pengarahan secara tertulis dan tidak tertulis disamping juga mengadakan pengawasan melalui piket harian dan melakukan tindakan bagi yang melanggarnya. Berhubungan dengan masalah itu Kepala madrasah memberikan konsep bahwa untuk tegaknya disiplin kami memulainya dengan pengarahan dan himbauan baik melalui rapat maupun melalui teguran secara lisan dan tulisan dan pengawasan terhadap guru-guru yang terlambat terutama hari senin karena adanya upacara bendera.

Selanjutnya pemberian motivasi merupakan salah satu faktor yang ikut menentukan keberhasilan kepala sekolah dalam memimpin madrasahnya. Satuan pendidikan yang merupakan sistem sosial, yang di dalamnya terdiri dari individu-individu yang memiliki karakteristik berbeda-beda, dan saling berhubungan (melayani) satu sama lainnya. Dalam kondisi seperti itu, motivasi dari kepala sekolah sangat dibutuhkan untuk mendukung tumbuh dan berkembangnya organisasi sekolah. Kepala madrasah memberikan kesempatan kepada guru untuk mengikuti pelatihan-pelatihan dalam rangka peningkatan profesionalisme. Selain itu juga memberikan fasilitas dan sarana parasana pembelajaran yang memadai sehingga proses pembelajaran dapat berlangsung dengan nyaman.

Dalam melaksanakan program pengajaran kepala madrasah telah melakukan supervisi secara bertahap, supervisi jangka pendek, jangka 
menengah dan jangka panjang untuk lima tahun ke depan yang ditekankan pada peningkatan mutu proses pembelajaran. Hasil yang diharapkan dari supervisi tersebut meliputi: pemenuhan kebutuhan sarana supervisi dan gagasan dalam pengembangan kualitas madrasah. Tindak lanjut terhadap hasil supervisi dilaksanakan sendiri oleh kepala madrasah dan Untuk lebih terarah pelaksanaan tindak lanjut tersebut dibuat jadwal kegiatan. Kegiatan tindak lanjut dilaksanakan di kantor madrasah atau di ruang belajar ketika guru yang akan dibimbing melakukan kegiatan pembelajaran. Mengunjungi guru yang sedang mengajar di kelas dalam kaitan menindaklanjuti atau membina guru yang masih mengalami kesulitan dalam proses pembelajaran harus membaritaukan guru yang bersangkutan. Kepala Madrasah mengungkapkan bahwa apabila hasil supervise pertama sudah baik maka tindaklanjutnya dilakukan pembinaan dalam semester itu dan sebaliknya apabila belum baik maka tindaklanjutnya dilakukan perbaikan dan dilanjutkan dengan supervisi yang ke dua.

Penerapan disiplin dapat ditegakan melalui pemberian reward and punishment. Reward dan punishment merupakan dua bentuk metode dalam memotivasi seseorang untuk melakukan kebaikan dan meningkatkan prestasinya. Kedua metode ini sudah cukup lama dikenal dalam dunia kerja. Tidak hanya dalam dunia kerja, dalam dunia penidikan pun kedua ini kerap kali digunakan. Namun selalu terjadi perbedaan pandangan, mana yang lebih diprioritaskan antara reward dengan punishment. Kepala madrasah memberikan penghargaan bagi guru-guru yang berprestasi bukan dengan financial/uang, tetapi penghargaan itu bersifat motivasi, ucapan terima kasih, dan paling tinggi adalah mempromosikan jabatan mereka. Sedangkan bagi guru-guru yang kurang disiplin kami panggil dan kami adakan pembinaan secara khusus.

Hasil temuan supervisi kepala MTs Swasta Miftahul Falah Diski yang perlu ditindaklanjuti meliputi: (a) Kesulitan guru-guru dalam menyiapkan perangkat pembelajaran, (b) kesulitan dalam melakukan kegiatan pembelajaran dengan model-model pembelajaran, (c) Kesulitan dalam penguasaan materi yang sulit, (d) Kesulitan dalam menciptakan kreativitas belajar siswa, (e) Kesulitan dalam manajemen kelas, (f) Kesulitan dalam penggunaan metode pembelajaran yang efektif, dan (g) Kesulitan untuk merubah cara-cara konvensional dalam mengajar. Kendala ini merupakan faktor utama yang dihadapi kepala dalam membina dan membimbing terhadap guru.

Usaha yang dilakukan kepala madrasah adalah adanya bimbingan keteladanan, pembinaan, pengembangan kreativitas dari pendidik dan tenaga kepandidikan. Diberlakukannya tata tertib dan kode etik warga madrasah, ketiga madrasah berusaha menciptakan suasana, iklim dan lingkungan yang kondusif untuk pembelajaran yang efisien. Kaitannya dengan disiplin dan tanggungjawab kita berpedoman pada Peraturan Direktorat Jendral Pendidikan Islam No 1 Tahun 2013 tentang disiplin kehadiran guru di lingkungan madrasah. Kepala sekolah dalam upaya peningkatan kinerja guru ini dibantu oleh wakil kepala sekolah urusan kurikulum dan guru bekerja dalam kelompok MGMP. Kepala sekolah selalu memerankan fungsinya untuk meningkatkan kreativitas kinerja para guru. Hal tersebut membuat guru dapat lebih bebas dan terbuka tentang hal yang baru dan dapat memberikan kesempatan untuk bertanggung jawab lebih besar terhadap tugas yang diberikan.

\section{Kepemimpinan Kepala MTs Swasta Miftahul Falah Diski}

Sebagai kepala madrasah kepemimpinan yang dijalankan dengan musyawarah dengan tujuan memberikan masukan, ada musyawarah ini sifatnya memberitakan kepada bawahan dengan memberikan motivasi kepada bawahan itu merupakan suatu kebijakan dari kepala madrasah. Selain itu bijaksana dalam hal memberikan keputusan kemudian menyelesaikan sebuah masalah dan bertanggungjawab dalam kepemimpinannya. Dalam hal rapat kepala madrasah cukup menghargai pendapat anggotanya, mengutamakan kepentingan orang banyak, tidak egois dan saling toleran.

Berdasarkan pengamatan peneliti bahwa kepala madrasah telah menjalankan peran kepemimpinannya secara baik itu tercermin dari iklim kerja yang menyenangkan. Kepala madrasah tidak memberikan batasan atau perbedaan antara kepala madrasah dengan seluruh dewan guru, staf dan tata usaha mereka semua berbaur menjadi satu kesatuan. Namun tetap adanya profesionalitas 
dimana ketika kegiatan belajar mengajar berlangsung mereka tetap profesional dan serius dalam melaksanakan tugasnya masing-masing dan ketika istirahat berlangsung di dalam ruang guru disitulah terjadi suasana keakraban dan rasa kekeluargaan, banyak candaan dan gurauan antara kepala madrasah dengan seluruh dewan guru dan tata usaha. Kepala madrasah juga sangat bersahabat dengan seluruh peserta didik namun tidak membuat kharisma dan wibawanya turun dihadapan peserta didik dan seluruh dewan guru.

Dapat diuraikan konsep kepemimpinan kepala madrasah dapat dilihat sebagai berikut: 1) Kepala madrasah rutin untuk memeriksa daftar hadir pegawai dan guru; 2) Setiap sekali dalam seminggu kepala madrasah melihat lingkungan sekolah; 3) Kepala madrasah rutin untuk memeriksa buku piket harian; 4) Kepala madrasah rutin dalam meneliti surat-surat masuk; 5) Kepala madrasah menugaskan tata usaha dalam penyelesaian surat atau masalah; 6) Kepala madrasah senantiasa mengontrol pekerjaan pesuruh; 7) Kepala madrasah rutin untuk memeriksa kebersihan kelas; 8) Kepala madrasah memaraf/menandatangani buku laporan dan piket; 8) Kepala madrasah rutin memeriksa rencana belanja bulanan dan pegawai.

Dengan demikian dalam menjalankan kepemimpinannya kepala sekolah telah melaksanakan kewajiban dan perannya semaksimal mungkin agar dapat tercapainya tujuan madrasah yang diharapkan serta terciptanya suasana kerja yang kondusif dan menyenangkan. Sehingga dapat disimpulkan bahwasanya kepemimpinan yang dijalankan oleh kepala madrasah di MTs. Swasta Miftahul Falah Diski sudah berjalan dengan baik selama masa pimpinannya. Dengan kepemimpinan yang demokratis kepala madrasah mampu menciptakan iklim kerja yang kondusif dan menyenangkan. Maka wajar MTs Swasta MIfathul Falah Diski memproleh akreditasi B dengan budaya senyum, salam, dan sapa.

Untuk merencanakan pelaksanaan kurikulum di madrasah maka pihak madrasah dengan segala stakeholder yang ada, melaksanakan rapat dalam rangka penyusunan kurikulum madrasah yang akan dilaksanakan pada tahun tersebut. Ketika guru mengajar, guru mengajar dengan perangkat mengajar seperti silabus dan
RPP ya itu tentunya sudah disusun diawal tahun pelajaran. Tentunya guru berusaha bagaimana untuk memberikan pengajaran yang terbaik untuk siswa-siswa di sini. Kesiapan guru selalu di dibimbing kepala madrasah dan wakil yang samasama memiliki.

Kepala madrasah dalam menjalankan peran kepemimpinannya adalah dengan mengaplikasikan program-program yang telah direncanakan dan disusun oleh kepala madrasah. Dalam mengaplikasikan program tersebut kepala madrasah harus bekerja secara maksimal agar perannya sebagai seorang pemimpin dapat terlaksana dengan baik, dengan begitu maka mutu pendidikan di madrasah yang dipimpinnya dapat mangalami kemajuan sesuai dengan standar mutu pendidikan nasional. Dalam hal ini, kepala madrasah setiap semester selalu mempersiapkan melalui musyawarah rencana kegiatan untuk satu semester. Hal ini menunjukkan bahwa kepala madrasah berperan sebagai menejer, sebagai educator dan sebagai motivator. Jadi, kepala madrasah berperan sebagai menejer itu tadi untuk mengimplementasikan visi misi madrasah, jadi itulah peran kepala madrasah. Sebagaimana peran kepala madrasah sebagai motivator, sebagai menejer maka untuk mencapai tadi, untuk mencapai tujuan tentu ada sebentuk program kerja dilaksanakan secara bersama-sama, secara terperinci, dan dilaksanakan oleh semua komponen yang ada di madrasah itu.

Mengenai langkah-langkah yang dilakukan dalam menjalankan program dalam meningkatan mutu pendidikan di MTs Swasta Miftahul Falah Diski adalah dengan memotivasi, dalam hal ini kepala madrasah memberikan motivasi kepada tenaga pendidik, kemudian memberikan motivasi kepada peserta didik. Disini dapat dilihat bahwa kepala madrasah memberikan peran sebagai motivator. Dengan peran ini direalisasikan melalui pengaturan lingkungan, suasana kerja, disiplin, dorongan, penghargaan secara efektif dan penyediaan sarana pembelajaran yang memadai. Yang paling signifikan adalah kepala madrasah dalam meningkatkan mutu pendidikan adalah meningkatkan kedisiplinan. Kedisiplinan guru, tata usaha dan siswa serta terus berusaha memfasilitasi sarana dan prasarana untuk memperlancar kegiatan belajar mengajar siswa. 
Berdasarkan uraian kegiatan kepala madrasah di atas dapat disimpulkan bahwa peran kepala madrasah dalam meningkatkan mutu pendidikan sebagai berikut: a) Kepala madrasah sebagai edukator yang memiliki kemampuan untuk membimbing guru, karyawan, siswa dan staf; b) Sebagai manager yang memliki kemampuan untuk menyusun program, menyusun organisasi personalia, menggerakkan masing-masing kinerja guru, staf dan karyawan, juga mengoptimalkan sumber daya madrasah; c) Sebagai leader (pemimpin) yang memliki kepribadian yang kuat, memahami kondisi anak buah dengan baik, memliki visi dan memahamai visi sekolah, mampu mengambil keputusan dan berkomunikasi; d) Sebagai inovator yang mampu mencari/menemukan gagasan baru untuk pembaharuan sekolah; e) Sebagai motivator yang mampu mengatur lingkungan kerja baik yang fisik maupun non fisik, serta mampu menerapkan prinsip penghargaan dan hukuman; f) Sebagai administator, mengelola administrasi kegiatan belajar mengajar dan bimbingan konseling serta mengelola administrasi kesiswaan, ketenagaan dan keuangan; g) Sebagai supervisor yang menyusun program supervisi, melaksanakan program supervisi dan menggunakan hasil supervisi.

Berdasarkan data yang diproleh bahwa kepala madrasah dalam menjalankan peran dan fungsinya sebagai seorang pemimpin, telah membuat beberapa perencanaan dan strategi untuk mewujudkan misi dan visi yang akan dicapai untuk kemajuan madrasah yaitu: a) Menyusun tujuh standar program kerja kepala madrasah, agenda kegiatan kepala madrasah, jadwal kerja kepala madrasah, program kerja tahunan, jadwal kegiatan madrasah, menjalankan fungsi dan tugas sebagai pengelolah madrasah, menjalankan kompetensi kepala madrasah dan menyusun program kinerja kepala madrasah sesuai dengan komponen, aspek dan indikator yang ingin dicapai; b) Kepala madrasah membuat rencana program kerja jangka panjang untuk bidang kurikulum, kesiswaan, humas, ketatalaksaan dan program organisasi dan manajemen.

Setiap program yang dilakukan dan telah diupayakan semaksimal mungkin, sudah tentu selalu saja ada kendala yang dihadapi. Demikian juga di MTs Swasta Miftahul Falah Diski, ada beberapa hambatan yang dihadapi dalam pelaksanaan program yang dilakukan. Adapun faktor penghambat tersebut adalah sebagai berikut: a) Hambatan keuangan, keuangan yang ada masih diutamakan untuk pembayaran honor guru, perbaikan ruang kelas, belanja ATK, perbaikan mobiler dan lain-lain; b) Dana yang diterima hanya dari dana BOS karena siswa-siswi yang bersekolah di sini tidak dimintai iuran SPP sama sekali, karena masyarakat di sini rata-rata dengan ekonomi menengah kebawah. Dengan demikian kebijakan itu dibuat supaya masyarakat banyak yang minat untuk bersekolah di sini; c) Dalam penerapan kurikulum bisa dikatakan lumayan baik, namun belum sempurna karena ada beberapa faktor yang mempengaruhinya, terutama madrasah ini letaknya di kampung atau dipedesaan sehingga motivasi belajar anak itu lebih rendah ketimbang siswa yang berada di luar, sehingga tingkat keseriusan itu lebih rendah.

Dari keseluruhan upaya lembaga pendidikan yang telah dilakukan di atas sesungguhnya merupakan satu rangkaian sistemis dalam mendorong peningkatan mutu tenaga pendidik atau guru itu sendiri, semua apa yang ingin di capai dari tujuan itu sesungguhnya ada peranan yang sangat penting dan dominan dari kepala madrasah. Dalam hal ini apa yang telah dilakukan oleh Madrasah Tsanawiyah Swasta Miftahul Falah Diski dalam upaya mendorong peningkatan mutu guru di lembaga tersebut, upaya yang sangat dominan telah dilakukan oleh seorang Kepala Madrasah.

Dari sedikit banyak upaya yang telah dilakukan oleh Kepala Madrasah dalam usaha meningkatkan mutu guru di madrasahnya tidaklah luput dari aspek-aspek berpengaruh yang dalam perjalanannnya menjadi satu penting, yakni aspek pendukung dan penghambat dalam upaya melakukan peranannya sebagai kepala madrasah untuk meningkatkan mutu guru di madrasah tersebut. Faktor pendukung itu adalah kekuatan dan peluang yang bisa didapat dan diperoleh dari unsur kekuatan yang ada di dalam dan dari luar madrasah itu sendiri dalam upaya menjalankan dan melaksanakan tujuan lembaga madrasah tersebut yang bersumber dari visi dan misi yang di buat. Peluang yang diperoleh tidak lain berupa kesempatan yang datang dan di dapat oleh madrasah untuk mengupayakan terwujudnya tujuan dan menjadikan lembaga tersebut maju dan berkembang. Sedangkan penghambat yang 
dimaksudkan adalah merupakan keadaan yang dapat menyebabkan pelaksanaan terganggu dan tidak terlaksana dengan baik.

Usaha yang akan dilakukan kepala madrasah dalam upaya meningktkan mutu lembaga pendidikannya secara umum dan mutu guru secara khusus sesungguhnya tidak bisa dilakukan sendirian atau berhasil guna tanpa adanya kerjasama yang sinergis dengan beberapa pemangku kebijakan lainnya yang selaras dan sinergis. Apapun usaha akan menjadi sia-sia jika tidak ada nya dukungan yang baik dari semua pihak. Sesungguhnya merupakan keberhasilan yang dicapai berkat kerjasama yang baik semua pihak, baik itu yayasan, lembaga itu sendiri dan semua guru yang menjadi bagian penting dari usaha peningkatan mutu guru tersebut, sehingga tujuan yang dicapai dapat berguna baik dan memberikan dampak pada peningkatan secara keseluruhan lembaga pendidikan itu sendiri.

Keberhasilan kepemimpinan berkaitan erat dengan peningkatan prestasi siswa, oleh karena itu didukung sumber daya manusia di madrasah yang merupakan unsur penting dalam sebuah organisasi pendidikan. Apabila gurunya berkualitas maka akan menghasilkan siswa-siswa yang berkualitas pula, begitu juga dengan pengelola madrasah apabila kinerja masing-masing pengelola madrasah sudah optimal maka kegiatan dan pelaksanaan di madrasah akan berjalan efektif. Maka dari itu, agar guru dan masing-masing pengelola madrasah semangat kerja dan terus meningkatkan kinerjanya, maka pihak madrasah membuat penilaian sebagai hadiah berupa kenaikan gaji melalui berbagai level.

Terdapat tiga syarat utama yang harus diperhatikan dalam pembangunan pendidikan agar dapat berkontribusi terhadap peningkatan kualitas sumber daya manusia terutama dalam peningkatan prestasi siswa di madrasah, yakni sarana dan prasarana yang modern, buku yang berkualitas, dan guru dan tenaga kependidikan yang profesional. Untuk merealisasikan kebijakan di atas, maka madrasah perlu melakukan manajemen peningkatan mutu. Hal ini sesuai denga peraturan pemerintah adalah sebagai berikut: a) Review, adalah proses mengharuskan seluruh komponen sekolah bekerja sama dengan berbagai pihak yang memiliki keterkaitan misalnya orangtua dan tenaga profesional untuk mengevaluasi keefektifan kebijakan sekolah, program dan pelaksanaannya, serta mutu lulusan; b) Benchmarking, merupakan kegiatan untuk menetapkan standar, baik proses maupun hasil yang akan dicapai dalam suatu periode tertentu. Untuk kepentingan praktis, standar tersebut direfleksikan dari realitas yang ada; c) Quality Assurance, sifatnya process oriented. Artinya, konsep ini mengandung jaminan bahwa proses yang berlangsung dilaksanakan sesuai dengan standar dan prosedur yang telah ditetapkan; d) Quality Control, merupakan suatu sistem untuk mendeteksi terjadinya penyimpangan kualitas output yang tidak sesuai dengan standar. Konsep ini berorientasi pada output untuk memastikan apakah output sesuai dengan standar.

Dengan demikian mutu pendidikan disebuah madrasah tidak akan meningkat apabila tidak ada pengembangan dan perubahan yang dilakukan kepala madrasah selaku pimpinan. Oleh karena itu, kepala madrasah dalam menjalankan peran kepemimpinannya harus senantiasa berupaya memberikan perubahan kearah yang lebih maju dengan melakukan manajemen peningkatan mutu. Dalam pelaksanaannya kepala madrasah selalu melibatkan warga madrasah agar sama-sama merasakan bahwa madrasah merupakan milik bersama. Dengan demikian kepemimpinan yang dijalankan kepala madrasah di MTs. Swasta Miftahul Falah Diski tergolong kepada tipe kepemimpinan demokratis dimana kepala madrasah selalu mengadakan musyawarah kepada seluruh dewan guru, staf dan tata usaha dalam menetapkan setiap keputusan yang akan diambil.

\section{SIMPULAN}

Kepemimpinan yang dijalankan kepala madrasah di MTs. Swasta Miftahul Falah Diski tergolong kepada tipe kepemimpinan demokratis dimana kepala madrasah selalu mengadakan musyawarah kepada seluruh dewan guru, staf dan tata usaha dalam menetapkan setiap keputusan yang akan diambil. Mutu pendidikan di MTs. Swasta Miftahul Falah Diski sudah memenuhi 8 Standar Nasioanal Pendidikan, dan dibuktikan dengan terakreditasinya MTs Swasta Miftahul Falah Diski dengan perolehan akreditasi B.

Peran kepemimpinan yang dijalankan kepala madrasah dalam meningkatkan mutu pendidikan di MTs. Swasta Miftahul Falah Diski yaitu (a) Sebagai edukator yang memiliki kemampuan untuk 
membimbing guru, karyawan, siswa dan staf. (b) Sebagai manager yang memliki kemampuan untuk menyusun program, menyusun organisasi personalia, menggerakkan masing-masing kinerja sumber daya madrasah. (c) Sebagai administator, mengelola administrasi kegiatan belajar mengajar dan bimbingan konseling serta mengelola administrasi kesiswaan, ketenagaan dan keuangan. (d) Sebagai supervisor yang menyusun program supervisi, melaksanakan program supervisi dan menggunakan hasil supervisi. (e) Sebagai leader yang memliki kepribadian yang kuat, memahami kondisi anak buah dengan baik, memliki visi dan memahamai visi sekolah, mampu mengambil keputusan dan berkomunikasi. (f) Sebagai inovator yang mampu mencari/menemukan gagasan baru untuk pembaharuan sekolah. (g) Sebagai motivator yang mampu mengatur lingkungan kerja baik yang fisik maupun non fisik, serta mampu menerapkan prinsip penghargaan dan hukuman. Faktor Penghambat dalam Meningkatkan Mutu Pendidikan di MTs. Swasta Miftahul Falah Diski dapat dilihat dari faktor internal dan eksternal. Faktor internal, yaitu faktor dana madrasah. Sedangkan faktor eksternal, yaitu faktor wilayah dan faktor lingkungan masyarakat

\section{DAFTAR PUSTAKA}

A'yuni, Q., (2016), Pola Kepemimpinan Kepala Madrasah Aliyah Negeri Kisaran dalam Pelaksanaan Pekerjaan di Kabupaten Asahan, Jurnal Administrasi Publik, 7 (1): 64-76

Danim, S. (2010). Kepemimpinan Pendidikan (Kepemimpinan Jenius (IQ+EQ), Etika, Perilaku Motivational dan Mitos. Bandung: Alfabeta.

Mulyasa, E. (2007). Menjadi Kepala Sekolah Profesional. Bandung: PT Remaja Rosdakarya.

Sarwono, J. (2006). Metode Penelitian Kualitatif dan Kuantitatif. Bandung: Graha Ilmu.

Siregar, A.B., Kusmanto, H. Isnaini. (2016), Evaluasi Kinerja Kepala Sekolah Menengah Kejuruan SeKabupaten Langkat Tahun 2015, Jurnal Administrasi Publik, 6 (1): 13-19

Sugiyono. (2010). Metode Penelitian Pendidikan, Pendekatan Kuantitatif, Kualitatif, dan R \& D. Bandung: Alfabeta.

Sukimadinata, N.S. (2012). Metode Penelitian Pendidika. Bandung: Citapustaka Media Perintis.

Syam, Y.H. (2005). Mendidik Anak ala Muhammad. Yogyakarta: Penerbit Sketsa.

Wahjosumidjo. (2005). Kepemimpinan Kepala Sekolah. Jakarta: Rajawali. 